\title{
The Relationship between Blood Glucose Level and Stamina of Sepak Takraw Athletes
}

\author{
Arfandi Akkase \\ Master Program in Sport Sciences \\ Universitas Negeri Yogyakarta \\ Yogyakarta, Indonesia \\ arfandi.ilara011a@gmail.com
}

\author{
B. M. Wara Kushartanti \\ Faculty of Sports Sciences \\ Universitas Negeri Yogyakarta \\ Yogyakarta, Indonesia \\ bm_warakushartanti@uny.ac.id
}

\begin{abstract}
- this study addresses the relationship between blood glucose level and the stamina of sepak takraw athletes. Eight sepak takraw athletes in Sidrap regency were involved in this study and were selected using a purposive sampling technique. Data was analyzed using a descriptive analysis technique and a set of test which includes normality, correlation and regression. The results of the correlation test generated a positive correlation between blood glucose level and stamina with a 0.000 significance level. In the meantime, regression analysis in the hypothesis test indicates significant correlation between blood glucose level and the stamina of sepak takraw athletes in Sidrap South Sulawesi $(\beta=0.953, T=$ 7.744, and $P=0,000<0,005$ ).
\end{abstract}

Keywords-blood glucose, stamina, sepak takraw

\section{INTRODUCTION}

Sepak takraw is built upon two main elements; attack and defense. The main goal of this game is to stop rally to the opponents' defense area [1]. In comparism to football, sepak takraw is relatively more difficult to play. Nevertheless, both games require their players to have good stamina to last through the full matches. Sepak takraw happens to be one of the most played sports in South Sulawesi. This sport is very popular in Sidrap district. Unfortunately, due to lack in several aspects, many athletes always fail to win any sepak takraw competition. One aspect contributing to their failure is their lack of stamina. Stamina is related to muscle work or muscles ability to perform their functions in certain period of time. Stamina is a bio motor component needed by the human body to perform physical activities and one of the most important components in physical fitness. Stamina is one's ability to keep doing intense work for a long period of time without serious fatigue. One of the aspects that promote one's stamina is a stable level of blood glucose. Blood glucose, contained in the human body is sugar exerted by the body from the consumption of food [3]. Blood glucose level is considered normal if it is between 80 to $100 \mathrm{mg} / \mathrm{dL}$. People with blood glucose level exceeding normal level are prone to diabetes mellitus [4]. This disease affects insulin production and insulin response to the body's ability. Blood glucose is exerted from food that contains carbohydrate. Carbohydrate is converted into glucose in the liver, after which the glucose then becomes the source of energy in the body. Glucose in human body serves as the fuel for metabolism process and the main source of energy for the brain. Skeletal muscles consume glucose as their fuels and store glycogen which serves as an energy source for muscles contraction (after being converted from glucose) [6]. In Sidrap South Sulawesi, many athletes lack understanding of how to measure glucose level and how glucose can promote body stamina.

\section{METHODS}

This study is designed as an associative study. Population and sample of this study are 8 sepak takraw athletes in Sidrap South Sulawesi. They were selected using purposive sampling technique. Data collection was conducted using two tests. In the first test, samples of the study were asked to do the Harvard step test. Meanwhile, in the second test, researchers took the blood samples of all participants using the easy touch $\mathrm{GCHb}$ device.

In the first test, participants stood facing the Harvard platform. After the instruction was given, they stepped up and down the platform, using metronome intervals for 5 minutes. If the participants stop before 5 minutes, the test and the stopwatch will be stopped simultaneously. After taking a one-minute break, participants' first, second and third heartbeats were counted for 30 seconds each.

$$
\text { Formula }=\frac{\text { Duration insecond } x 100}{2 x(D N 1+D N 2+D N 3)}
$$

TABLE I. ASSESSMENT CRITERIA

\begin{tabular}{|c|c|c|}
\hline Criteria & Score & Grade \\
\hline Extremely poor & 1 & $<50$ \\
\hline Poor & 2 & $50-64$ \\
\hline Fair & 3 & $65-79$ \\
\hline Good & 4 & $80-89$ \\
\hline Excellent & 5 & $>90$ \\
\hline
\end{tabular}

In the second test, participants began by cleaning their fingertips using cotton and alcohol. After taking a strip of the glucose test, the lancet is inserted into their fingertips and the drop placed on the strip, they would wait for about 6 seconds before seeing the results. 
TABLE II. NORMAL BLOOD GLUCOSE LEVEL

\begin{tabular}{|c|c|}
\hline $\mathbf{M g} / \mathbf{d L}$ & Interpretation \\
\hline 35 & Extremely low \\
\hline 55 & Low \\
\hline 75 & Slightly low \\
\hline 80 & Normal \\
\hline 100 & Normal \\
\hline $90-100$ & Normal before eating \\
\hline 150 & Normal after eating \\
\hline 180 & Maximum after eating \\
\hline 360 & Extremely high \\
\hline 400 & Maximum \\
\hline 600 & Dangerously high \\
\hline
\end{tabular}

\section{RESUlt AND DisCUSSION}

TABLE III. NORMALITY TEST

\begin{tabular}{|c|c|c|c|c|c|c|c|}
\hline $\begin{array}{c}\text { Vari } \\
\text { able }\end{array}$ & $\mathbf{N}$ & $\begin{array}{c}\text { absol } \\
\text { ute }\end{array}$ & positive & negative & $\begin{array}{c}\text { Ks } \\
-\mathbf{Z}\end{array}$ & $\begin{array}{c}\text { Asymp } \\
\text {.sig } \\
\text { failed }\end{array}$ & ket \\
\hline GD & 8 & $\begin{array}{c}0.18 \\
6\end{array}$ & 0.186 & 0.186 & $\begin{array}{c}0.5 \\
26\end{array}$ & 0,945 & $\begin{array}{c}\text { Nor } \\
\text { mal }\end{array}$ \\
\hline DT & 8 & $\begin{array}{c}0.19 \\
0\end{array}$ & 0.190 & 0.185 & $\begin{array}{c}0.5 \\
39\end{array}$ & 0.935 & $\begin{array}{c}\text { Nor } \\
\text { mal }\end{array}$ \\
\hline
\end{tabular}

TABLE IV. CORRELATION TEST

\begin{tabular}{|c|c|c|c|c|}
\hline Variable & $\mathbf{N}$ & $\boldsymbol{\beta}$ & To & Sig \\
\hline $\mathrm{X}-\mathrm{Y}$ & 8 & 0.953 & 0.744 & 0.000 \\
\hline
\end{tabular}

\section{TABLE V. REGRESSION TEST}

\begin{tabular}{|c|c|c|c|c|}
\hline Variable & $\boldsymbol{\beta}$ & To & P & Ket \\
\hline $\begin{array}{c}\text { GD (X) } \\
\text { DT (Y) }\end{array}$ & 0.953 & 7.744 & 0.000 & significant \\
\hline
\end{tabular}

In reference to the above results, it is seen that correlation between independent variable (blood glucose level) and dependent variable (stamina) exists. The results also indicate a normal distribution and significance level below $0.05 \quad(p<0.05)$ for all data. To understand the correlation between blood glucose and stamina, this research conducted a correlation test that resulted in a positive significant correlation between blood glucose and stamina with a 0.000 significance level.

Regression of blood glucose and stamina in the hypothesis test generates a $\beta$ value of 0.953 , T value of 7.744 , and a $\mathrm{P}$ value of $0.000(\mathrm{P}<0.005)$. Therefore, significant correlation between blood glucose and stamina exists.

\section{CONCLUSION}

This study suggests that decrease in blood glucose level influences the stamina. Sepak takraw athletes with low blood glucose level are most likely to have poor stamina. Similarly, those with high blood glucose level will also have poor stamina. On the other hand, athletes with a stable blood glucose level have good stamina which supports their physical performance to the maximum. In conclusion, all these shows there is correlation between blood glucose level and the stamina of sepak takraw athletes in Sidrap South Sulawesi.

\section{REFERENCES}

[1] P. K. Suppiah, "Visual Perception of Kuda and Sila Service Techniques in Sepak Takraw," Journal of Movement, Health and Exercise, 2012, pp. 25-37.

[2] K. H. Cooper, et al., "Meningkatkan Daya Tahan Tubuh untuk Orang yang Mudah Sakit”. Bandung: Kuadran, 2007.

[3] H. Kang, C. M. Ripsin, "Management of Blood Glukose in Type 2 Diabetes Melitus", American Family Physicean, 2009, vol. 79, no. 1.

[4] K. H. Gabbay, "Glycosilated Hemoglobins and Long- Term Blood Glucose Control in Diabetes Mellitus". The Journal of Clinical Endocrinology and Metabolism, 2009, vol. 44, no. 5.

[5] M. A. Irawan, "Glukosa dan Metabolisme Energi". Polton Sport Science \& Performance Lab., 2007.

[6] A. C. Guyton, J. E. Hall, "Texbook of Medical Physiology". Philadelphia, PA, USA, Elsevier Saunders, 2006. 